\title{
Salivary gland choristoma in large bowel
}

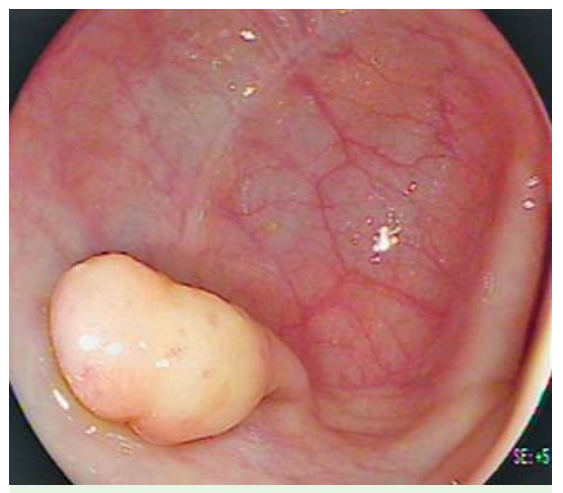

Fig. 1 Endoscopic image of pedunculated yellowish polypoid lesion.

The occurrence of heterotopic tissue in the large bowel is relatively rare. The most common type of tissue in such heterotopia is gastric mucosa, but rare cases of pancreatic and salivary tissue are also reported in literature. All cases of salivary choristomas reported in literature arose in the rectum-anal canal region [1-5].

Here we report a submucosal salivary gland choristoma in the sigma of a 55year-old woman who underwent largebowel endoscopy for colorectal carcinoma screening.

At gross examination of the bowel we found a pedunculated polypoid lesion of $1 \mathrm{~cm}$ situated at $19 \mathrm{~cm}$ from the anal verge, resembling a submucosal lipoma without other mucosal alterations ( $\boldsymbol{\nabla}$ Fig. $\mathbf{1}$ ).

At histological examination we found a small aggregate of acinar glands with mixed mucous-serous features in the submucosa. In addition, we found an intercalated duct composed of a double layer of cells - epithelial and myoepithelial - that reached the mucosal surface ( $\bullet$ Fig. 2 ). Immunohistochemical staining was performed in order to confirm the nature of the lesion. The glands were positive for lysozyme antibody and negative for pancreatic amylase, S-100 protein, chromogranin, and synaptophysin. The morphology of the glands and the immunostaining were consistent with the typical architecture of normal mixed salivary glands (๑ Fig.3).

Only four other cases of salivary gland heterotopia in the large bowel have previously been reported in the literature;

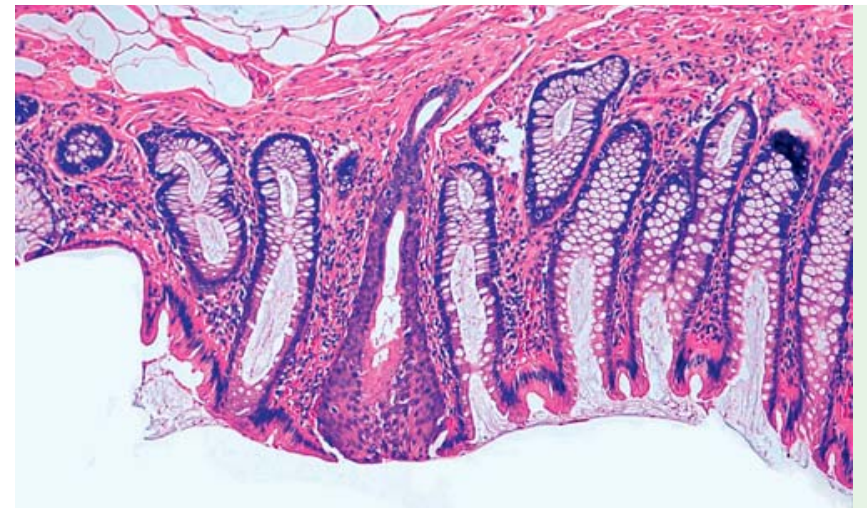

Fig. 2 Intercalated duct connected with the mucosal surface (hematoxylin and eosin; original magnification $\times 10)$.
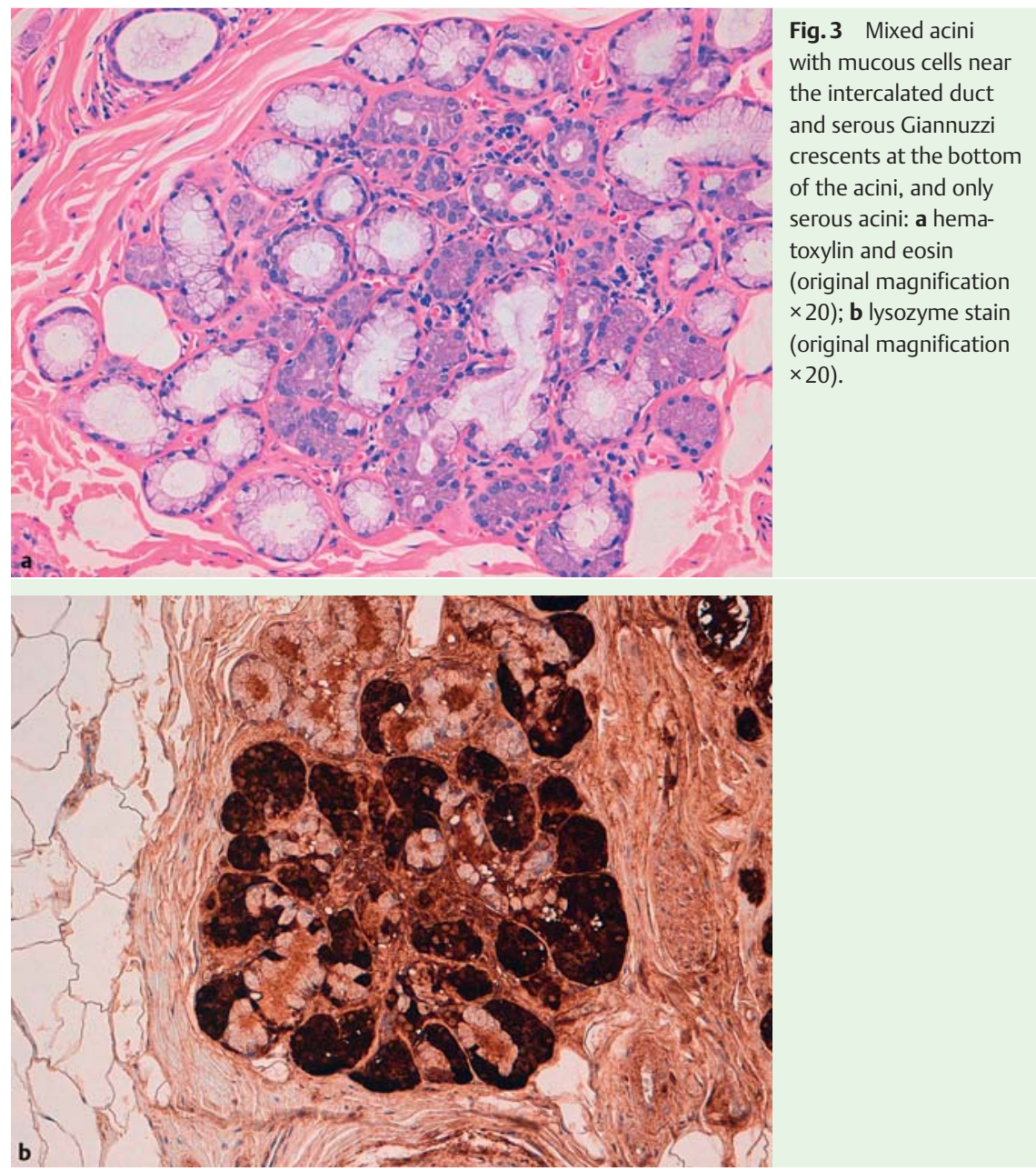

all were a histologically mixed type, all arose in the rectum-anal canal mucosa, and they were most prevalent in men. Two cases also showed gastric heterotopia, something that we have not found in the case reported here.
Some authors explained the presence of heterotopic salivary gland tissue in the large bowel as anomalous differentiation of embryonic remnants or as metaplastic changes [1-3]. We think that the absence of other anatomic structures in the sigma, 
such as perianal glands, in which metaplastic changes can occur, suggests that the mixed salivary glands we found are true choristomas.

Endoscopy_UCTN_Code_CCL_1AD_2AJ

Competing interests: None

\section{F. Maffini ${ }^{1}$, A. Vingiani ${ }^{1}$, D. Lepanto ${ }^{1}$,} G. Fiori' ${ }^{2}$, G. Viale ${ }^{1,3}$

${ }^{1}$ Division of Pathology and Laboratory Medicine, European Institute of Oncology, Milan, Italy

${ }^{2}$ Division of Endoscopy, European Institute of Oncology, Milan, Italy

${ }^{3}$ University of Milan School of Medicine, Milan, Italy

\section{References}

1 Weitzner S. Ectopic salivary gland tissue in submucosa of rectum. Dis Colon Rectum 1983; 26: 814-817

2 Downs-Kelly E, Hoschar AP, Prayson RA. Salivary gland heterotopia in the rectum. Ann Diagn Pathol 2003; 7: 124-126

3 Evans CS, Goldman RL. Seromucinous (salivary) ectopia of the perianal region. Arch Dermatol 1987; 123: 1277-1277

4 Wolff $M$. Heterotopic gastric epithelium in the rectum: a report of three new cases with a review of 87 cases of gastric heterotopia in the alimentary canal. Am J Clin Pathol 1971; 55: 604-616

5 Shindo K, Bacon HE, Holmes EJ. Ectopic gastric mucosa and glandular tissue of a salivary type in the anal canal concomitant with a diverticulum in hemorrhoidal tissue: report of a case. Dis Colon Rectum 1972; 15 : $57-62$

\section{Bibliography}

Dol http://dx.doi.org/

10.1055/s-0031-1291498

Endoscopy 2012; 44: E13-E14

(c) Georg Thieme Verlag KC

Stuttgart · New York

ISSN 0013-726X

\section{Corresponding author}

\section{F. Maffini, MD}

Divisione di Anatomia Patologica e Medicina di Laboratorio

Istituto Europeo di Oncologia Via Giuseppe Ripamonti, 435

I-20141 Milano

ITALY

Fax: + 39-02-57489417

fausto.maffini@ieo.it 